\title{
Fournier's Gangrene: Analysis of Risk Factors Affecting Mortality in a Tertiary Urology Referral Center
}

\author{
Fournier Gangreni: Tersiyer Bir Üroloji Referans Merkezinde Mortaliteye Etki Eden Risk \\ Faktörlerinin Analizi
}

\author{
(1) Sinharib Çitgez, (1) Çetin Demirdağ, (1) Mustafa Özkaya, (1) Berin Selçuk, (1) Ahmet Erözenci \\ Istanbul University-Cerrahpaşa, Cerrahpaşa Faculty of Medicine, Department of Urology, Istanbul, Turkiye
}

\section{What's known on the subject? and What does the study add?}

Aggressive treatment is the main approach for the management of Fournier gangrene (FG). The mortality rate is between $3 \%$ and $45 \%$ in the literature. For this reason, to know the risk factors affecting mortality for FG may help surgeons in their daily practice.

\begin{abstract}
Objective: We aimed to investigate the risk factors affecting mortality in patients with Fournier's gangrene (FG).

Materials and Methods: Records of 48 male patients, who were admitted to our urology clinic between November 2011 and June 2018 , were analyzed. The patients were divided into two groups according to their survival status. statistical analyses were done to determine the risk factors for mortality.

Results: The mean age was $53.9 \pm 12.61$ years. 41 patients were discharged (group 1 ) and 7 were deceased (group 2). The mortality rate was $14.6 \%$. Increased age, Fournier's Gangrene Severity Index (FGSI) scores, prolonged operative time, presence of immunosuppressive diseases, abdominal spread of the disease, history of cystostomy, mechanical ventilation requirement, and multiple micro-organism in wound culture were found to be risk factors for mortality in patients with FG.

Conclusion: Increased age, high FGSI scores, increased operative time, presence of immunosuppressive diseases, history of cystostomy, abdominal spread of the disease, mechanical ventilation requirements, and multiple micro-organism in wound culture were thought to affect mortality in patients with FG.
\end{abstract}

Keywords: Fournier's gangrene, Mortality, Risk factor

Öz

Amaç: Fournier kangreni (FG) hastalarında mortaliteyi etkileyen risk faktörlerini araştırmayı amaçladık.

Gereç ve Yöntem: Kasım 2011 ve Haziran 2018 arasında 48 erkek hastanın kayıtları analiz edildi. Hastalar sağkalım durumlarına göre iki gruba ayrıldı. Mortaliteye etki eden risk faktörlerini belirlemek için istatistiksel analizler yapıldı.

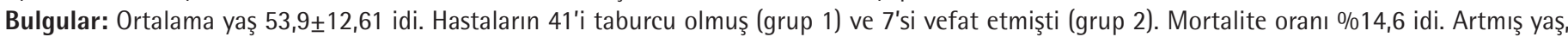
artmış Fournier Gangreni Severity Indeks (FGSI) skorları, artmış operasyon süresi, immünosüpresyon hastalığı olması, sistostomi yapılması, hastalığın abdominal yayılması, mekanik ventilasyon ihtiyacı, yara kültüründe multipl mikroorganizma saptanması FG'de mortalite için risk faktörleri olarak bulundu.

Sonuç: İleri yaş, artmış FGSI skorları, artmış operasyon süresi, immünosüpresyon hastalığı olması, sistostomi yapılması, hastalığın abdominal yayılımının olması, mekanik ventilasyon ihtiyacı, yara kültüründe multipl mikroorganizma saptanmasının FG'si olan hastalarda mortaliteyi etkilediği düşünülmektedir.

Anahtar Kelimeler: Fournier gangreni, Mortalite, Risk faktörü

Correspondence: Sinharib Çitgez MD, İstanbul University-Cerrahpaşa, Cerrahpaşa Faculty of Medicine, Department of Urology, İstanbul, Turkiye Phone: +90 5323122377 E-mail: drsinharib@yahoo.com ORCID-ID: orcid.org/0000-0002-5163-7648

Received: 24.02.2019 Accepted: 24.03.2019

Cite this article as: Çitgez S, Demirdağ Ç, Özkaya M, Selçuk B, Erözenci A. Fournier's Gangrene: Analysis of Risk Factors Affecting Mortality in a Tertiary Urology Referral Center. J Urol Surg 2019;6(3):196-200.

๑Copyright 2019 by the Association of Urological Surgery / Journal of Urological Surgery published by Galenos Publishing House. 


\section{Introduction}

Fournier's gangrene (FG) is a disease of the perineal, genital or perianal regions characterized by necrotizing fasciitis due to synergistic polymicrobial infection (1). Since delay in diagnosis and treatment can be lethal, it is very important that the symptoms are not missed even if non-specific. It is a serious disease which is seen in emergency departments of general surgery and urology clinics and it is associated with high mortality rates due to its insidious course and requires urgent surgical intervention with appropriate antibiotic therapy (2).

In this retrospective study, we aimed to analyse the factors that affect prognosis in patients treated for FG.

\section{Materials and Method}

We retrospectively reviewed the records of patients who underwent surgery with FG diagnosis between 2011 and 2018 in our clinic. A total of 48 male patients were included in the study. Clinical and demographic data such as age, comorbidity, Fournier's Gangrene Severity Index (FGSI) score (Table 1) and perioperative data were recorded. The patients were divided into two groups according to their survival status.

We performed radical debridement of the affected devitalized tissues in all patients after presentation. Initial empiric antibiotherapy with imipenem + teicoplanin and clindamycin was given in the outpatient clinic and continued. The dressings were changed daily. Wound debridement was performed every 48 hours with sedation in the operating room. Vacuum assisted closure (VAC) was used for wound treatment (Figure 1). All necrotic areas were debrided until the healthy tissue was seen in the wound. If necessary, the patients were managed in the intensive care unit (ICU). If the skin defect was not self-healing, treatment with tertiary closure, split-thickness skin grafting (STSG), was performed for reconstruction.

\section{Statistical Analysis}

Statistical analyses were performed using the Statistical Package for the Social Sciences (SPSS) version 21.0 software (IBM SPSS Statistics for Windows, version 21.0. monk, NY: IBM Corp., Armonk, NY). The Pearson chi-square and Fisher's exact tests

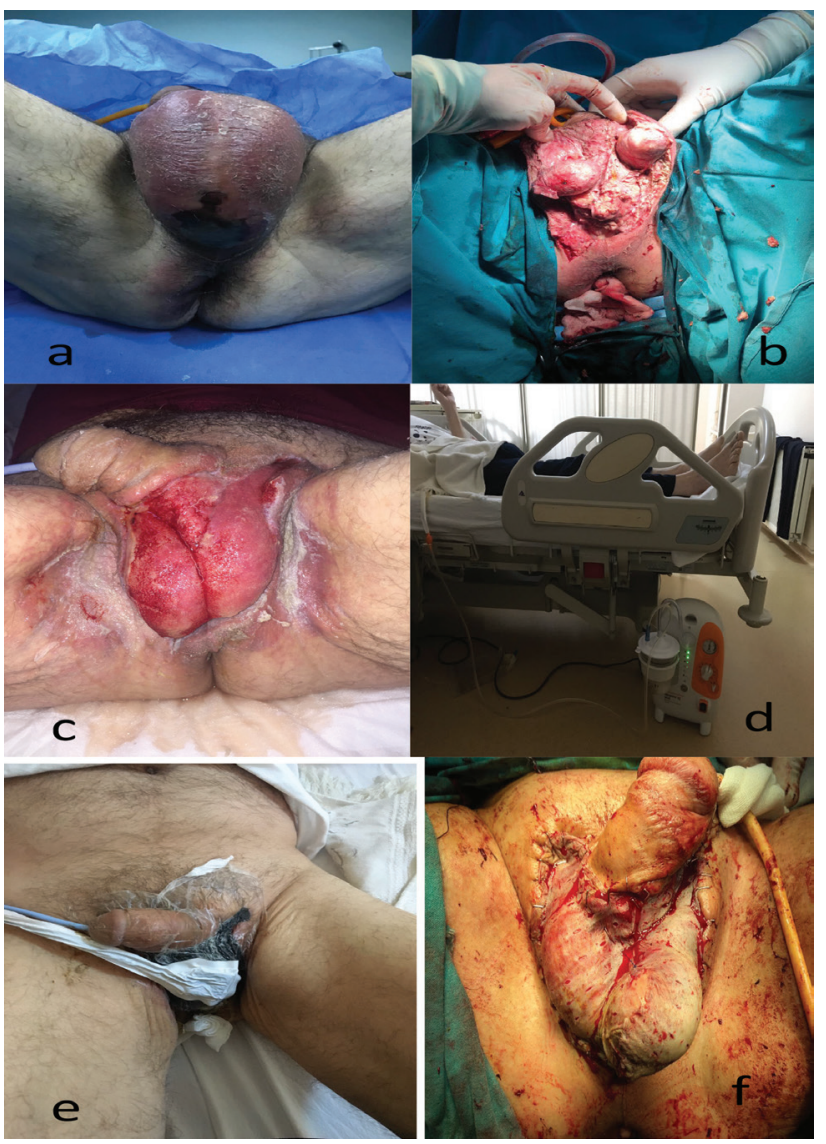

Figure 1. (a) Presentation of a patient with FG (b) Debridement was performed at the operating room (c) Granulation tissue was formed $(d, e)$ VAC therapy procedure (f) Skin graft applied.

Table 1. Fournier Gangrene Severity Index scoring system

\begin{tabular}{|c|c|c|c|c|c|c|c|c|c|}
\hline \multirow{2}{*}{$\begin{array}{l}\text { Physiologic variable/point } \\
\text { assignment }\end{array}$} & \multicolumn{4}{|c|}{ High abnormal values } & \multirow{2}{*}{$\begin{array}{l}\text { Normal } \\
0\end{array}$} & \multicolumn{4}{|c|}{ Low abnormal values } \\
\hline & +4 & +3 & +2 & +1 & & +1 & +2 & +3 & +4 \\
\hline Temperature $\left({ }^{\circ} \mathrm{C}\right)$ & $>41$ & $39-40.9$ & - & $38.5-38.9$ & $36-38.4$ & $34-35.9$ & $32-33.9$ & $30-31.9$ & $<29.9$ \\
\hline Heart rate & $>180$ & $140-179$ & $110-139$ & - & $70-109$ & - & $55-69$ & $40-54$ & $<39$ \\
\hline Respiratory rate & $>50$ & $35-49$ & - & $25-34$ & $12-24$ & $10-11$ & $6-9$ & - & $<5$ \\
\hline Serum sodium (mmol/L) & $>180$ & $160-179$ & $155-159$ & $150-154$ & $130-149$ & - & $120-129$ & $110-119$ & $<110$ \\
\hline Serum potassium (mmol/L) & $>7$ & $6-6.9$ & - & $5.5-5.9$ & $3.5-5.4$ & $3-3.4$ & $2.5-2.9$ & - & $<2.5$ \\
\hline $\begin{array}{l}\text { Serum creatine }(\mathrm{mg} / 100 \mathrm{~mL}) \\
\text { ' } 2 \text {, acute renal failure }\end{array}$ & $>3.5$ & $2-3.4$ & $1.5-1.9$ & - & $0.6-1.4$ & - & $<0.6$ & - & - \\
\hline Hematocrit & $>60$ & - & $50-59$ & $46-49$ & $30-45$ & - & $20-29$ & - & $<20$ \\
\hline WBC (total/mm³ '1000) & $>40$ & - & $20-39.9$ & $15-19.9$ & $3-14.9$ & - & $1-2.9$ & - & $<1$ \\
\hline $\begin{array}{l}\text { Serum bicarbonate (venous, } \\
\mathrm{mmol} / \mathrm{L} \text { ) }\end{array}$ & $>53$ & $41-51.9$ & - & $32-40.9$ & $22-31.9$ & - & $18-21.9$ & $15-17.9$ & $<15$ \\
\hline
\end{tabular}


were used for analyzing differences between the categorical variables, and the Kruskal-Wallis and Mann-Whitney $U$ tests were used for analyzing differences between means. A $p$ value of less than 0.05 was considered statistically significant. The study protocol was approved by the ethics committee of Cerrahpasa Faculty of Medicine.

\section{Results}

The mean age of the patients was $53.90 \pm 12.61$ years. Fourtyone patients were discharged (group 1) and 7 deceased (group 2). The demographic data is given in Table 2. The most common cause of the disease was urological causes (25 patients; $52.1 \%$ ). The most common immunosuppressive disease was diabetes mellitus (12 patients; 25.0\%). Two patients were human immunosuppressive virus (HIV)-positive.

The most frequently isolated pathogen in wound culture was Escherichia coli (27 patients; 56.2\%). Other identified microorganisms were Klebsiella pneumoniae in 12 (25.0\%), Streptococcus in $4(8.3 \%)$, Staphylococcus in $3(6.2 \%)$ and Pseudomonas in 2 (4.1\%). Nineteen patients (39.6\%) had polymicrobial infection ( $\geq 2$ microorganisms identified) .

Table 2. Characteristics of patients

\begin{tabular}{|c|c|}
\hline Patient characteristics & $\mathbf{n}$ \\
\hline Number of patients & 48 \\
\hline $\begin{array}{l}\text { Age (year) } \\
\text { Mean (range) }\end{array}$ & $53.9(36-78)$ \\
\hline $\begin{array}{l}\text { BMI (kg/m²) } \\
\text { Mean (range) }\end{array}$ & $28.2(18.7-42.4)$ \\
\hline $\begin{array}{l}\text { Hematocrite } \\
\text { Mean (range) }\end{array}$ & $34.3(25.6-51.9)$ \\
\hline $\begin{array}{l}\text { Operation time (min) } \\
\text { Mean (range) }\end{array}$ & $162.4(40-540)$ \\
\hline $\begin{array}{l}\text { FGSI } \\
\text { Mean (range) }\end{array}$ & $3.2(1-11)$ \\
\hline $\begin{array}{l}\text { Albumin } \\
\text { Mean (range) }\end{array}$ & $3.3(2.3-4.4)$ \\
\hline $\begin{array}{l}\text { Leukocyte count value } \\
\text { Mean (range) }\end{array}$ & $12.060(7.320-18.530)$ \\
\hline $\begin{array}{l}\text { Etiology } \\
\text { - Urogenital } \\
\text { - Anorectal } \\
\text { - Skin-based }\end{array}$ & $\begin{array}{l}25(52.1 \%) \\
19(39.6 \%) \\
4(8.3 \%)\end{array}$ \\
\hline $\begin{array}{l}\text { Pathogen in wound culture } \\
\text { - E.coli } \\
\text { - Klebsiella } \\
\text { - Other }\end{array}$ & $\begin{array}{l}27(56.2 \%) \\
12(25.0 \%) \\
9(18.8 \%)\end{array}$ \\
\hline $\begin{array}{l}\text { Length of hospital stay (days) } \\
\text { Mean (range) }\end{array}$ & $36.7(10-93)$ \\
\hline
\end{tabular}

FGSI: Fournier Gangrene Severity Index, BMI: Body mass index
VAC therapy was used for wound management in 33 patients. The mean number of debridements was 3 (1-9). Colostomy and cystostomy were established in $5(10.4 \%)$ and $3(6.3 \%)$ patients, respectively. The wound was closed conveniently for tertiary closure in $27(56.2 \%)$ patients. The wounds in $14(29.1 \%)$ patients were reconstructed with STSG.

A total of 14 (29\%) patients required treatment in the ICU with a mean duration of 7 days (1-29). Of these, seven underwent mechanical ventilation. The mean duration of postoperative mechanical ventilation was $4 \pm 2.1(1-29)$ days. A total of 7 patients died due to multi-organ failure associated with septic shock. The mortality rate was found to be $14.6 \%$.

There was a significant difference between the groups in age $(p=0.001)$, FGSI score $(p=0.001)$, operative time $(p=0.001)$, presence of immonosuppressive disease $(p=0.001)$, history of cystostomy $(p=0.002)$, abdominal spread of the disease $(p=0.001)$, mechanical ventilation requirement $(p=0.001)$ and multiple microorganism in wound culture $(p=0.001)$ (Table 3 ).

\section{Discussion}

The rate of mortality associated with FG has been reported to be between $3 \%$ and $45 \%$ (3). While mortality rate was $80 \%$ in the first series published, the rate decreased to $40 \%$ in the last 15 years (4). Causes of death from the disease include severe sepsis, coagulopathy, acute renal failure, diabetic ketoacidosis and multiple organ failure (3). Early aggressive treatment reduces mortality. Therefore, the important factor affecting the clinical outcome is timely and adequate surgical debridement. Furthermore, accurate estimation of mortality risk may be a guide for the management of FG. For instance, FGSI is a powerful predictor of mortality associated with FG. In addition, in the literature, many factors have been shown to have a negative effect on survival, e.g., increased age, widespread disease, delay in treatment, presence of shock or sepsis on admission, positive blood culture, increased level of urea, anorectal origin of infection, diabetes mellitus and immunosuppressive condition (5). In our study, the mortality rate was found to be $14.6 \%$. Also, increased age, and operative time, high FGSI score, presence of immonosuppressive disease, history of cystostomy, abdominal spread of the disease, mechanical ventilation requirement and multiple micro-organisms in wound culture were thought to affect mortality in this study.

Perianal infections are the most common cause of FG (4). The most common sites of infection are the gastrointestinal system (30$50 \%)$, genitourinary tract (20-40\%) and skin (20\%). However, in Eke's series, the etiological factors for FG were diabetes mellitus in 20\% and alcohol abuse in 9\%, and the sources of FG were dermatological in 24\%, anorectal in 21\%, and urological in 19\% (3). In our study, the etiology was urogenital infection in 52.1\% 
Table 3. The predictive factors for mortality

\begin{tabular}{|c|c|c|c|}
\hline & $\begin{array}{l}\text { Group } 1 \\
(n=41)\end{array}$ & $\begin{array}{l}\text { Group } 2 \\
(n=7)\end{array}$ & p \\
\hline $\begin{array}{l}\text { Age (year) } \\
\text { Mean (+SD) }\end{array}$ & $50.5 \pm 9.8$ & $73.4 \pm 8.6$ & 0.001 \\
\hline $\begin{array}{l}\text { Operation time }(\mathrm{min}) \\
\text { Mean }(+\mathrm{SD})\end{array}$ & $125.7 \pm 97.4$ & $377.1 \pm 178.9$ & 0.001 \\
\hline $\begin{array}{l}\text { Body mass index (BMI) } \\
\text { Mean (+SD) }\end{array}$ & $25.27 \pm 4.8$ & $24.82 \pm 4.6$ & 0.775 \\
\hline $\begin{array}{l}\text { FGSI score } \\
\text { Mean }( \pm S D)\end{array}$ & $2.0 \pm 1.0$ & $10.1 \pm 1.1$ & 0.001 \\
\hline $\begin{array}{l}\text { Hospitalization time (days) } \\
\text { Mean }( \pm S D)\end{array}$ & $38.6 \pm 26.8$ & $25.4 \pm 8.5$ & 0.258 \\
\hline $\begin{array}{l}\text { Immunosuppressive disease } \\
\text { - Yes } \\
\text { - No }\end{array}$ & $\begin{array}{l}14 \\
27\end{array}$ & $\begin{array}{l}0 \\
7\end{array}$ & 0.001 \\
\hline $\begin{array}{l}\text { Cystostomy } \\
\text { - Yes } \\
\text { - No }\end{array}$ & $\begin{array}{l}0 \\
41\end{array}$ & $\begin{array}{l}3 \\
4\end{array}$ & 0.002 \\
\hline $\begin{array}{l}\text { Colostomy } \\
\text { - Yes } \\
\text { - No }\end{array}$ & $\begin{array}{l}5 \\
36\end{array}$ & $\begin{array}{l}0 \\
7\end{array}$ & 0.438 \\
\hline $\begin{array}{l}\text { Abdominal spread } \\
\text { - Yes } \\
\text { - No }\end{array}$ & $\begin{array}{l}1 \\
40\end{array}$ & $\begin{array}{l}6 \\
1\end{array}$ & 0.001 \\
\hline $\begin{array}{l}\text { Orchiectomy } \\
\text { - Yes } \\
\text { - No }\end{array}$ & $\begin{array}{l}12 \\
29\end{array}$ & $\begin{array}{l}0 \\
7\end{array}$ & 0.113 \\
\hline $\begin{array}{l}\text { Mechanical ventilation } \\
\text { - Yes } \\
\text { - No }\end{array}$ & $\begin{array}{l}13 \\
28\end{array}$ & $\begin{array}{l}0 \\
7\end{array}$ & 0.001 \\
\hline $\begin{array}{l}\text { Micro-organism in wound } \\
\text { culture } \\
\text { - Multiple } \\
\text { - Single }\end{array}$ & $\begin{array}{l}19 \\
22\end{array}$ & $\begin{array}{l}7 \\
0\end{array}$ & 0.001 \\
\hline
\end{tabular}

SD: Standard deviation, FGSI: Fournier Gangrene Severity Index, BMI: Body mass index

of patients. Genitourinary tract-related diseases were more common in our patients. This is because the urogenital diseases are being treated by the urology clinic in our hospital.

Increased age, diabetes mellitus, chronic liver disease, chronic renal failure, alcoholism, smoking and immunosuppressive conditions are risk factors for FG. Diabetes mellitus, the most common concomitant disease (12-70\%) in patients with $\mathrm{FG}$, is a predisposing factor for the disease (6). There is a decrease in chemotaxis, phagocytosis and cellular digestive function in diabetes mellitus leading to increased susceptibility to infections (7). Similarly, we found that diabetes mellitus, was the most common comorbid disease in this study (25\% of the patients). In addition, 2 patients (4.2\%) were found to be HIV-positive.
The FGSI was developed by Laor et al. (8) using vital findings and some laboratory data to determine the severity and prognosis of infection in FG patients. In their 15-year study, they found that a FGSI score of $>9$ was associated with a $75 \%$ probability of death and a score of $<9$ with a $78 \%$ probability of survival. FGSI score is a valid and effective tool commonly used in many studies for determining the clinical outcome in patients with FG (9). Different scoring systems have been studied to predict survival and prognosis. Bozkurt et al. (9) evaluated mortality associated with FG using three different scoring systems.

As a result, FGSI score, laboratory risk indicator for necrotizing fasciitis score and neutrophil-to-lymphocyte ratio were all found to be capable of predicting worse prognosis. We used the FGSI in our study. Similarly, FGSI scores were significantly higher in group 2 than in group 1 in our study $(p=0.001)$ and an increased FGSI score was thought to correlate with mortality.

Aerobic and anaerobic bacteria can be isolated in patients with FG. The most commonly isolated microorganisms are E. coli (80-43\%), Klebsiella pneumoniae, Bacteroides, Pseudomonas, Staphylococcus, Streptococcus, Clostridium, Peptostreptococcus and Enterobacteriaceae $(10,11)$. These infections are frequently polymicrobial (12). It is recommended to start a broad-spectrum antibiotic treatment with double and triple combinations before surgery (13). Depending on cultureantibiogram results, the same treatment may be continued or proper antibiotic substitution may be required. Our patient group was similar to the previous publications in terms of the most common microorganisms and reproduction of more than one microorganism. The most frequently isolated pathogens in the wound culture were E. coli (56.2\%) and Klebsiella (25\%). Also, multiple microorganisms were isolated in 39.6\% of the patients. When FG was detected, empiric antibiotherapy with a combination of intravenous imipenem + teicoplanin and clindamycin was started. According to the culture-antibiogram results, the antibiotic treatment was revised.

Aggressive resuscitation, broad spectrum antibiotic use and early surgical drainage are important in the treatment of FG $(12,13)$. All necrotic tissues are removed by debridement and the procedure is repeated to control infection. If the anorectal area and sphincters are involved, colostomy may be preferred to reduce contamination. Urinary catheterization or cystostomy is also recommended $(11,12,13,14)$. Similarly, 5 of our patients underwent colostomy and 3 patients underwent cystostomy. Also, the mean number of debridement was 3 (1-9) in our study. The number of patients undergoing cystostomy was significantly higher in group $2(p=0.002)$. Mortality rate was also found to be higher in patients with abdominal distention $(p=0.001)$. However, no significant difference was found between group 1 and group 2 in terms of mean duration of hospitalization or length of hospital stay in the ICU. However, mechanical 
ventilation requirement was significantly higher in group 2 than in group $1(p=0.001)$.

The last step in the treatment of FG is the process of closing the large wound defect. In most cases, especially small defect wounds simply improve as secondary healing. However, STSG is the most widely used and preferred method for wounds with large defects. VAC procedure, which has gained popularity in the recent years, has contributed significantly to this period of the treatment by accelerating wound healing. (14). By placing sterile foam dressing with an evacuation tube connected to an adjustable vacuum pump into the wound bed, thus, applying negative pressure to the entire wound bed, VAC accelerates wound healing by reducing edema, increasing blood flow fibroblast migration and cell proliferation. In our study, VAC therapy was used for wound management in 33 patients $(68.7 \%)$.

\section{Study Limitations}

This study has several limitations. Firstly, it was a retrospective study. Secondly, we could not perform logistic regression analyses. FG patients are treated in the general surgery or urology clinics depending on the affected area and system. In some cases, co-operation of both clinics is needed. The fact that only the outcomes of patients treated in the urology department were evaluated and the small sample size were other limitations of this study. Future prospective studies are warranted in order to overcome all the aforementioned limitations.

\section{Conclusion}

In conclusion, in this retrospective study, increased age, high FGSI scores, increased operative time, presence of immunosuppressive disease, history of cystostomy, abdominal spread of the disease, mechanical ventilation requirement, multiple micro-organism in wound culture are thought to associate with mortality in patients with FG.

\section{Ethics}

Ethics Committee Approval: The study protocol was approved by the ethics committee of Cerrahpaşa Faculty of Medicine (approval number: 83045809/604.01/02).

Informed Consent: Consent form was filled out by all participants.

Peer-review: Externally and internally peer-reviewed.

\section{Authorship Contributions:}

Surgical and Medical Practices: S.Ç., Ç.D. Concept: S.Ç., Ç.D. Design: S.Ç., Ç.D., M.Ö. Data Collection or Processing: Ç.D., M.Ö.,
S.Ç., B.S. Analysis or Interpretation: S.Ç., A.E., B.S. Literature Search: M.Ö., B.S. Writing: S.Ç., Ç.D., M.Ö.

Conflict of Interest: No conflict of interest was declared by the authors.

Financial Disclosure: The authors declared that this study received no financial support.

\section{References}

1. Smith G, Bunker C, Dinneen M. Fournier's gangrene. Br J Urol 1998;81:347355.

2. Morais H, Neves J, Maciel Ribeiro H, Ferreira M, Guimarães N, Azenha N, Dias $R$, Fonseca $A$, Conceição L. Case series of Fournier's gangrene: Affected body surface area: The un- derestimated prognostic factor. Ann Med Surg (Lond) 2017;16:19-22.

3. Eke N. Fournier's gangrene: a review of 1726 cases. Br J Surg 2000;87:718728.

4. Thwaini A, Khan A, Malik A, Cherian J, Barua J, Shergill I, Mammen K. Fournier's gangrene and its emergency management. Postgrad Med J 2006;82:516-519.

5. Yilmazlar T, Ozturk E, Alsoy A, Ozguc H. Necrotizing soft tissue infections: APACHE II score, dissemination, and survival. World J Surg 2007;31:18581862.

6. Taviloglu K, Cabioglu N, Cagatay A, Yanar H, Ertekin C, Baspinar I, Ozsut $\mathrm{H}$, Guloglu R . Idiopathic necrotizing fasciitis: risk factors and strategies for management. Am Surg 2005;71:315-320.

7. Norton KS, Johnson LW, Perry T, Perry KH, Sehon JK, Zi- bari GB. Management of Fournier's gangrene: an eleven year retrospective analysis of early recognition, diagnosis, and treatment. Am Surg 2002;68:709-713.

8. Laor E, Palmer LS, Tolia BM, Reid RE, Winter HI. Outcome prediction in patients with Fournier's gangrene. J Urol 1995;154:89-92.

9. Bozkurt O, Sen V, Demir O, Esen A. Evaluation of the utility of different scoring systems (FGSI, LRINEC and NLR) in the management of Fournier's gangrene. Int Urol Nephrol 2015;47:243-248.

10. Baykal K, Albayrak S, Inal H, Elbuken E, Dündar K, Onol Y. Fournier's disease: adjunctive hyperbaric oxygen therapy to classic therapy. Int J Urol 1996;3:161-162

11. Chawla SN, Gallop C, Mydlo JH. Fournier's gangrene: an analysis of repeated surgical debridement. Eur Urol 2003;43:572-575.

12. Jeong HJ, Park SC, Seo IY, Rim JS. Prognostic factors in Fournier gangrene. Int J Urol 2005:12:1041-1044.

13. Yanar H, Taviloglu K, Ertekin C, Guloglu R, Zorba U, Cabioglu N, Baspinar I. Fournier's gangrene: risk factors and strategies for management. World $\mathrm{J}$ Surg 2006;30:1750-1754.

14. Ozturk E, Ozguc H, Yilmazlar T. The use of vacuum assisted closure therapy in the management of Fournier's gangrene. Am J Surg 2009;197:660-665. 